\title{
UNDERSTANDING SPATIAL DRIVERS OF DEFORESTATION IN THE LUKI BIOSPHERE RESERVE, DEMOCRATIC REPUBLIC OF CONGO
}

\author{
OPELELE, O. M. ${ }^{1,2,3}-$ YU, Y. $.^{1,2^{*}}-$ FAN, W. $.^{1,2^{*}}-$ LUBALEGA, T. ${ }^{4,5}-$ CHEN, C. ${ }^{1,2}-$ \\ KACHAKA, S. K. ${ }^{3}$ \\ ${ }^{1}$ School of Forestry, Northeast Forestry University, Harbin 150040, Heilongjiang, P. R. China \\ ${ }^{2}$ Key Laboratory of Sustainable Forest Ecosystem Management-Ministry of Education, School \\ of Forestry, Northeast Forestry University, Harbin 150040, Heilongjiang, P. R. China \\ ${ }^{3}$ Department of Natural Resources Management, Faculty of Agricultural Sciences, University of \\ Kinshasa, 117 Kinshasa XI, Mont-Amba/Lemba, Democratic Republic of Congo \\ ${ }^{4}$ Institut National pour l'Étude et la Recherche Agronomiques (INERA/Luki), Antenne de \\ Gestion et Conservation des Ressources Naturelles, Province Kongo Central, Luki, Democratic \\ Republic of Congo \\ ${ }^{5}$ Université de Kikwit. Faculté des Sciences Agronomiques, Département de Phytotechnie, BP \\ 76 Kikwit, Democratic Republic of Congo \\ ${ }^{*}$ Corresponding authors \\ e-mail: fanwy@163.com or yuying4458@163.com; phone: +861-394-605-5384 \\ (Received $18^{\text {th }}$ Aug 2021; accepted $23^{\text {rd }}$ Nov 2021)
}

\begin{abstract}
Understanding factors that are driving land use/land cover change is one of the major steps that should be rationally addressed for the purpose of sustainable management of natural resources. The present study examines four spatial drivers affecting deforestation in the Luki Biosphere Reserve over the last three decades (1987-2020), where forest resources are prone to multiple human pressures compromising their sustainability. These are: distance from the nearest road; population density; elevation; and slope. Change detection analysis was performed on classified Landsat images to generate the Boolean map with two categories including forest change and no change. GIS and topographic data were used to compute spatial drivers of deforestation. Additionally, the logistic regression model was used to assess the effect of the spatial drivers on forest conversion, and determine the drivers that significantly influence forest conversion. The study results revealed a major change in the landscape that led to the loss of forest land, and gain in other land use classes. However, the regression model was statistically significant $(\mathrm{p}<0.01)$, suggesting that all the spatial drivers (independent variables) were significantly related to forest conversion. Distance to roads and population density have been identified as the most significant spatial drivers of deforestation over the last three decades. However, although slope and elevation also significantly affected forest conversion, but when compared to two other variables, their effects were moderate. It has been noted that the impact of these spatial drivers was spatially related to socioeconomic and demographic aspects. This study provides valuable information that could benefit the managers, policy-makers, and local authorities in their decision-making processes, especially for the purpose of environmental monitoring.
\end{abstract}

Keywords: logistic regression, spatial drivers, land usel land cover change, Luki Biosphere Reserve, Democratic Republic of Congo

\section{Introduction}

The concept of land cover is defined by the type of natural area on the land, while land use relates to the type of human activities carried out on the land or the current use of the land (Lambin, 2006; Rawat and Kumar, 2015; McConnett, 2015). Forest conversion has 
become a global concern due to the major role of forest resources in not only providing several resources for survival of human population, but also in their role for the mitigation of the climate change effects. Land use change constitutes an important source of carbon emissions due to human activities (Henders et al., 2015; Li et al., 2017; Zhou et al., 2021); and can lead to natural ecosystem degradation (Foley et al., 2005; Moghadasi et al., 2017; Sharma et al., 2019), fragmentation of habitats (Sun and Southworth, 2013; Adhikari and Hansen, 2018; Diuk-Wasser et al., 2021; Opelele et al., 2021), and loss of wildlife corridors (Nandy et al., 2007; Sharma et al., 2018; Powers and Jets, 2019). Also, ecosystem services such as biodiversity maintenance, food production, and climate regulation can be significantly affected by land use and land cover change (Verburg and Overmars, 2009; González et al., 2012; Al Kafy et al., 2021; Opelele et al., 2021). Therefore, factors driving land use change should be fully examined to provide a good understanding of their effect in order to provide valuable information to decision-makers. The drivers of land use/land cover change are multidimensional and can be derived from different facets including socioeconomic factors, institutional factors, and humanenvironment systems (Geist and Lambin, 2001; Overmars and Verburg, 2005).

Several studies have been conducted to examine the effects of spatial drivers (i.e. proximity to town and roads, elevation, slope, population density, and rainfall) on land use/land cover change (Lambin et al., 2001; Sulieman, 2018; Maitima et al., 2010). These studies have provided the data necessary for improving our comprehension of factors that drive land use/land cover change, and for planning land use for sustainable development of local communities. However, studies regarding the effects of spatial drivers on land use/land cover change in the Luki Biosphere Reserve are yet to be conducted. Given the spatio-temporal dynamic nature of the drivers of land use/land cover change, it is crucial to further examine them to obtain more accurate information that can support the decision-making process.

Meanwhile, the expansion of human activities has negatively impacted land use/land cover in the Luki Biosphere Reserve and its surroundings for a long time. The land use/land cover change process in this reserve continues to reduce the extent or area of different natural ecosystems, including forest lands, hence impacting the related ecosystem services. Several studies have noted that the proliferation of villages around the Reserve, added to this the increase in the population, of which the majority depends on forest resources for their survival, are the main causes of deforestation and forest degradation in the Luki Biosphere Reserve (Doumenge, 1990; Pendje and Mbaya, 1992; Gata, 1997; Nyange, 2014). However, the spatial drivers of land use/land cover change in this region are poorly studied and less understood.

In this research, the distance from roads, elevation, slope, population density was considered as spatial drivers of land use change in the Luki biosphere reserve. In fact, the distance to roads indicates the accessibility to natural resources by road, and subsequently their utilization. In addition, population density determines the forest clearance rate to establish cropland, and the magnitude of usage of forest resources in terms of providing various forest products (Kamwi et al., 2015). In another way, slope and elevation are often key with regards to the potential of the land use. For instance, areas reserved for construction are preferably allocated on flat land with good traffic conditions and water supply, while steeper land is mostly occupied by forest lands (Olaya, 2009; Buckley, 2010). Qasim et al. (2013) reported that changes observed in the landscape are also caused by physical factors, including slope and altitude. According to the authors, the choice of land use activity may be determined by the slope and altitude of an area. For example, 
agricultural areas are often allocated to the low elevation land because of the accessibility to the facility. With the recurrent change in socioeconomic, demographic, institutional and political conditions in the region, it could be evident to expect for certain changes in the spatial drivers. Despite the fact that the aforementioned drivers have been revealed to be significant in the process of land use change, their applicability in the current land use change process in the Luki biosphere reserve has not been proved yet, in order to support decision-making process.

In this context, the present study intended to examine how spatial drivers including, population density, distance from roads, slope, and elevation influenced deforestation in the Luki Biosphere Reserve during the last three decades, by using logistic regression techniques. In fact, the logistic regression model has been successfully used to evaluate land use changes and its related drivers (Loza, 2004; Siles, 2009; Arekhi, 2011; Mustafa et al., 2018; Wang et al., 2019; Buya et al., 2020). Thus, forest cover change was regarded as the dependent variable in the logistic regression and the distance from roads, elevation, slope, population density, were considered as explanatory variables. The findings of the present study will provide new understandings of spatial drivers associated with land use change in the Luki biosphere reserve, in order to support the establishment of sustainable land management strategies for the Luki biosphere reserve.

\section{Materials and Methods}

\section{Study area}

This study was conducted in the Luki Biosphere Reserve, the Democratic Republic of Congo (DRC) (Figure 1). According to Angoboy et al. (2019), Luki covers an area of about 33000 hectares. It was created in 1937 and was recognized by UNESCO as a Biosphere Reserve in 1979. The Luki Biosphere Reserve is located at the eastern boundary of the Mayombe forest, and remains a sample relic of the Mayombe vegetation (Lubini, 1997). The annual average rainfall ranges from $1150 \mathrm{~mm}$ to $1500 \mathrm{~mm}$. The annual average temperature ranges between $25^{\circ} \mathrm{C}$ and $30^{\circ} \mathrm{C}$ (Lubalega et al., 2018). The region is located within a humid tropical climate Aw5 according to the Köppen classification (Peel et al., 2007). The soils are generally ferrallitic and acidic (Sénéchal et al., 1998). Additionally, these soils are characterized by a low content of cations. Presently, the Luki Reserve is conserved with the support of the DRC government institutions and other partners including the WWF. Nevertheless, the natural resources of the Luki Reserve are prone to tremendous anthropogenic pressures, mainly due to local population activities, such as slash-and-burn agriculture, wood energy, bush fires, fuelwood, illegal logging, etc. This compromises the sustainability of natural resources in the Reserve.

The Figure 2 shows the temporal variation of temperature and precipitation over the last ten decades.

\section{Land use/land cover classification}

Landsat images and Digital Elevation Model were downloaded from google earth engine (https://code.earthengine.google.com) and United States Geological Survey (USGS) Earth Resources Observation Systems (EROS) Data Center (EDC) (http://glovis.usgs.gov). Road maps were downloaded from the OpenStreetMap website (https://www.openstreetmap.org/). Landsat images used in the present study are described in Table 1. 


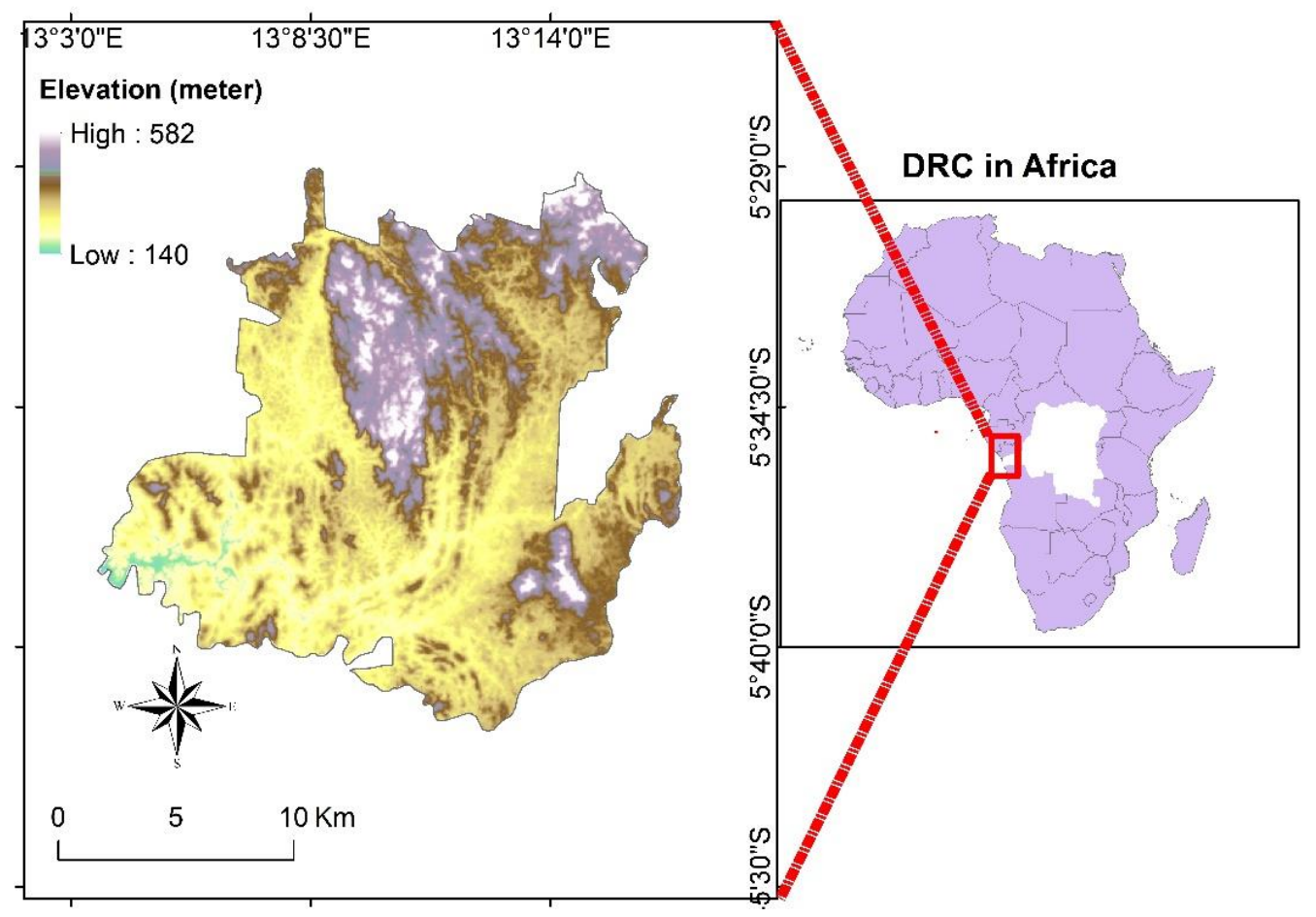

Figure 1. Location of the Luki Biosphere Reserve

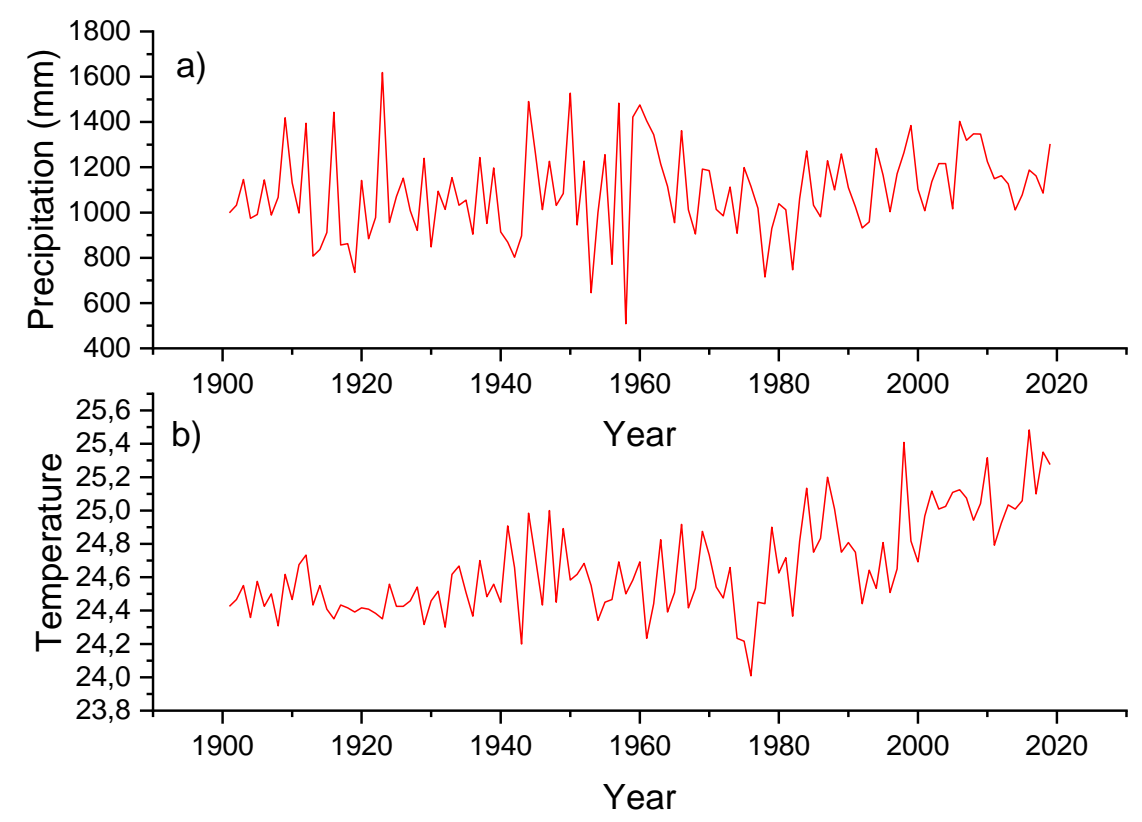

Figure 2. Annual temperature (in degree Celsius) and precipitation variation, from the year 1901 to 2019 (Harris et al., 2020)

We used the FLAASH method to perform radiometric and atmospheric correction for the Landsat images of the years 1987, 2002, and 2020. Then, the Luki's landscape was classified into different land use/land cover classes of which, forest land, complex of degraded and young secondary forest, fallow land and fields, savanna, and built-up area. 
These land use/land cover classes were grouped into two categories including forest land that comprises the complex of degraded and young secondary forest and forest land. The second category was the non-forest land that comprises fallow land and fields, savanna, and built-up area. Field data were collected in 2020 for the purpose of creating the testing and training data for each land use/land cover class. Then the maximum likelihood algorithm was used to carry out the supervised classification on the two images. It has been reported that this algorithm provides better land use/land cover classification results (Vadrevu, 2013). Kappa statistics and overall accuracy were computed to evaluate the image classification accuracy (Congalton and Mead, 1983; Pijanowski et al., 2005; Keshtkar et al., 2017).

Table 1. Description of Landsat data

\begin{tabular}{|c|c|c|c|c|c|}
\hline Data Type & Name & Pixel Size & Wavelength & Description & Year \\
\hline \multirow{7}{*}{ Landsat 4 TM } & B1 & $30 \mathrm{~m}$ & $0.45-0.52 \mu \mathrm{m}$ & Blue & \multirow{7}{*}{1987} \\
\hline & B2 & $30 \mathrm{~m}$ & $0.52-0.60 \mu \mathrm{m}$ & Green & \\
\hline & B3 & $30 \mathrm{~m}$ & $0.63-0.69 \mu \mathrm{m}$ & Red & \\
\hline & B4 & $30 \mathrm{~m}$ & $0.76-0.90 \mu \mathrm{m}$ & Near infrared & \\
\hline & B5 & $30 \mathrm{~m}$ & $1.55-1.75 \mu \mathrm{m}$ & Shortwave infrared 1 & \\
\hline & B6 & $30 \mathrm{~m}$ & $10.40-12.50 \mu \mathrm{m}$ & Thermal Infrared 1. & \\
\hline & B7 & $30 \mathrm{~m}$ & $2.08-2.35 \mu \mathrm{m}$ & Shortwave infrared 2 & \\
\hline \multirow{11}{*}{$\begin{array}{l}\text { Landsat } 8 \\
\text { OLI/TIRS }\end{array}$} & B1 & $30 \mathrm{~m}$ & $0.43-0.45 \mu \mathrm{m}$ & Coastal aerosol & \multirow{11}{*}{2020} \\
\hline & B2 & $30 \mathrm{~m}$ & $0.45-0.51 \mu \mathrm{m}$ & Blue & \\
\hline & B3 & $30 \mathrm{~m}$ & $0.53-0.59 \mu \mathrm{m}$ & Green & \\
\hline & B4 & $30 \mathrm{~m}$ & $0.64-0.67 \mu \mathrm{m}$ & Red & \\
\hline & B5 & $30 \mathrm{~m}$ & $0.85-0.88 \mu \mathrm{m}$ & Near infrared & \\
\hline & B6 & $30 \mathrm{~m}$ & $1.57-1.65 \mu \mathrm{m}$ & Shortwave infrared 1 & \\
\hline & B7 & $30 \mathrm{~m}$ & $2.11-2.29 \mu \mathrm{m}$ & Shortwave infrared 2 & \\
\hline & B8 & $15 \mathrm{~m}$ & $0.52-0.90 \mu \mathrm{m}$ & Band 8 Panchromatic & \\
\hline & B9 & $15 \mathrm{~m}$ & $1.36-1.38 \mu \mathrm{m}$ & Cirrus & \\
\hline & B10 & $30 \mathrm{~m}$ & $10.60-11.19 \mu \mathrm{m}$ & Thermal infrared 1 & \\
\hline & B11 & $30 \mathrm{~m}$ & $11.50-12.51 \mu \mathrm{m}$ & Thermal infrared 2 & \\
\hline
\end{tabular}

\section{Spatial analysis}

From the three land use/land cover maps produced for the years 1987, 2002 and 2020, a change map in each category (forest and non-forest land) was created using TerrSet software. Boolean maps $(0=$ no change, $1=$ change $)$ were then created for two periods (1987-2002 and 2002-2020), for the purpose of implementing the logistic regression model. The logistic regression model was used to map the probability of occurrence for forest lands to non-forest land. However, for this study, we used distance to roads, population density, elevation, and slope as independent variables (Table 2). Although these factors have been considered to drive land use change processes, there are still no studies that have examined the impact of these variables on the land use change in the Luki Biosphere Reserve. In this study, these factors were selected and used to perform logistic regression with each land use/land cover conversion being considered as dependent variable. The choice of independent variables depended on data availability. Also, these independent variables were selected because they represented the process believed to drive the land use/land cover change in the region. 
Table 2. Independent variables used in the logistic regression model

\begin{tabular}{|c|c|c|}
\hline Variable & Description & Sources \\
\hline Population density & Population density in square km & Bas-fleuve district surveys \\
\hline Distance to roads & $\begin{array}{l}\text { Distance in }(\mathrm{km}) \text { from a middle of } \\
\text { a pixel to the nearest road }\end{array}$ & Field data and OpenStreetMap \\
\hline Digital elevation model & $\begin{array}{l}\text { The elevation value (in meter) for } \\
\text { each pixel } \\
\text { The maximum rate of change in } \\
\text { elevation from a given cell to its } \\
\text { neighbors }\end{array}$ & USGS \\
\hline
\end{tabular}

Roads vector data was converted into raster data, and the distance from roads map was created using the proximity tools in QGIS (version 2.18). The nearest distance was computed by evaluating the shortest distance between the random pixels and near roads. Additionally, the population density map was created through the interpolation tool using the IDW technique. Population data was collected during our survey in each village located within the Luki Biosphere Reserve. The slope map was computed from elevation data using spatial tool analysis in ArcGIS 10.1. The extract function in R software was used to extract all image attributes related to each of the land use/land cover conversion. Further steps were followed to map the predicted probabilities of occurrence and produce probability maps. These maps are important in highlighting the relationship between spatial distribution of land use/land cover and the spatial drivers. R (version 3.6.1 (201907-05)) and SPSS (version 20)) software were used to perform all analyses related to variable extraction and regression model.

\section{Logistic regression implementation to assess spatial drivers of land use/land cover change}

Here, the logistic regression was performed to measure the relationship between the derived spatial variables and LULC change outcome. Logistic regression is a powerful tool that can allow the simultaneous analysis of several explanatory variables, while avoiding the effect of confounding factors (Sperandei, 2014). The binary logistic regression was used since the outcome variable (forest change) had two categories (no change $=0$, change $=1$ ). The magnitude of strength between spatial drivers and forest conversion was measured by computing the odds ratio. A statistically significant association ( $p$-value less than 0.05) between spatial drivers and the dependent variable was then considered. To avoid problems induced by multicollinearity in the estimation of regression coefficients, we computed Pearson's correlation to examine the correlation between the spatial variables. Finally, the Variance Inflation Factor (VIF) and tolerance (I/VIF) were computed to analyze the collinearity among the spatial drivers (Field, 2013). The workflow of the present research is illustrated in Figure 3. The basic logistic regression model can be presented as follows:

$$
\operatorname{Logit}(\mathrm{P})=\ln \left(\frac{P}{1-p}\right)=\beta_{0}+\beta_{1} x_{1}+\beta_{2} x_{2}+\beta_{3} x_{3}+\beta_{4} x_{4}
$$

where $\beta 0$ is the intercept, $\beta i$ are the regression coefficients, and xi represents the set of independent variables. 


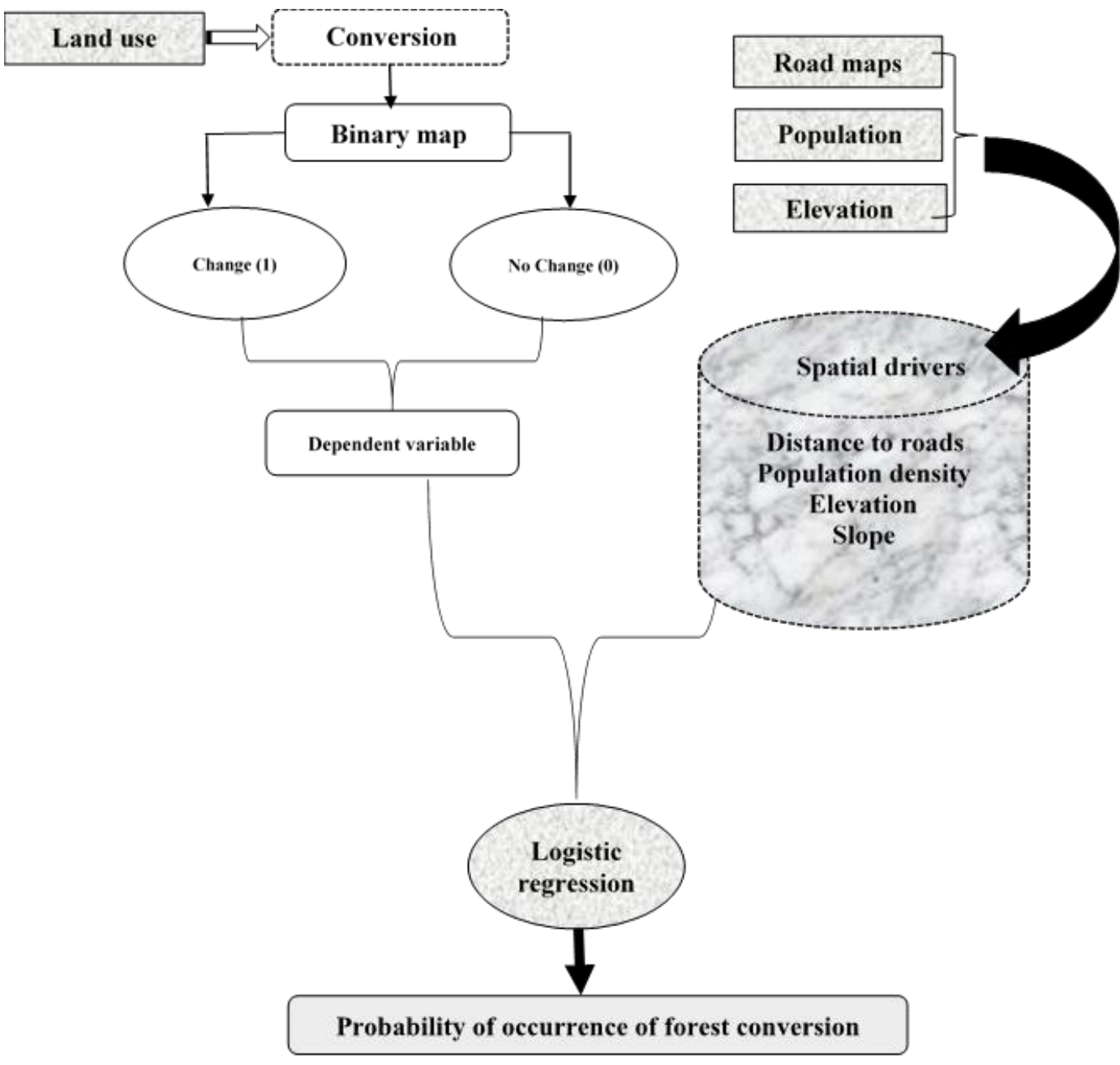

Figure 3. The workflow of the training and simulation processes

The area under the curve method was analyzed to evaluate the performance of the model (Metz, 1978; Hanley et al., 1983). Table 2 illustrates the independent variables used to examine the house-hold forest dependency in the Luki Biosphere Reserve.

\section{Results}

\section{Land Use/Land Cover conversion from 1987 to 2020}

Change detection method was used to analyze the past land use/land cover change (1987-2020) in the Luki Biosphere Reserve. For all classified images, the estimated overall accuracy was more than $80 \%$ (Table 3 ).

The results of land use/land cover change from the year 1987 to 2020 are shown in Figure 4 and Table 4. The Luki's landscape was found to have undergone major changes during the period under study. This is because all the land use/land cover classes experienced either an increase or a decrease in terms of their area. There was a decrease in forest land, while savannah, the complex of degraded and young secondary forest, built-up and fallow land and fields experienced an increase. However, the fallow land and fields' class received the greatest increase, although the built-up area also doubled in size. 
Table 3. Image classification accuracy

\begin{tabular}{|c|c|c|c|c|c|c|}
\hline \multirow[b]{2}{*}{ LULC Categories } & \multicolumn{2}{|l|}{1987} & \multicolumn{2}{|c|}{2002} & \multicolumn{2}{|c|}{2020} \\
\hline & $\begin{array}{c}\text { Producer's } \\
\text { Accuracy }(\%)\end{array}$ & $\begin{array}{c}\text { User's } \\
\text { Accuracy } \\
(\%)\end{array}$ & $\begin{array}{c}\text { Producer's } \\
\text { Accuracy } \\
(\%)\end{array}$ & $\begin{array}{c}\text { User's } \\
\text { Accuracy } \\
(\%)\end{array}$ & $\begin{array}{c}\text { Producer's } \\
\text { Accuracy } \\
(\%)\end{array}$ & $\begin{array}{c}\text { User's } \\
\text { Accuracy } \\
(\%)\end{array}$ \\
\hline Forest land & 90.7 & 91.9 & 93.9 & 96.3 & 99.05 & 98.05 \\
\hline Savannah & 86.7 & 86.7 & 93.3 & 91.3 & 89.28 & 97.16 \\
\hline $\begin{array}{l}\text { Complex of degraded and } \\
\text { young secondary forest }\end{array}$ & 89.7 & 90.2 & 91.1 & 94.2 & 92.3 & 94.1 \\
\hline Fallow land and fields & 92.3 & 90.6 & 94.7 & 92.3 & 96.19 & 75.75 \\
\hline Builtup area & 90.3 & 90.3 & 91.7 & 91.7 & 98.48 & 66.41 \\
\hline Overall accuracy (\%) & 89.16 & & 93.6 & & 97.17 & \\
\hline Kappa coefficient & 0.86 & & 0.91 & & 0.92 & \\
\hline
\end{tabular}

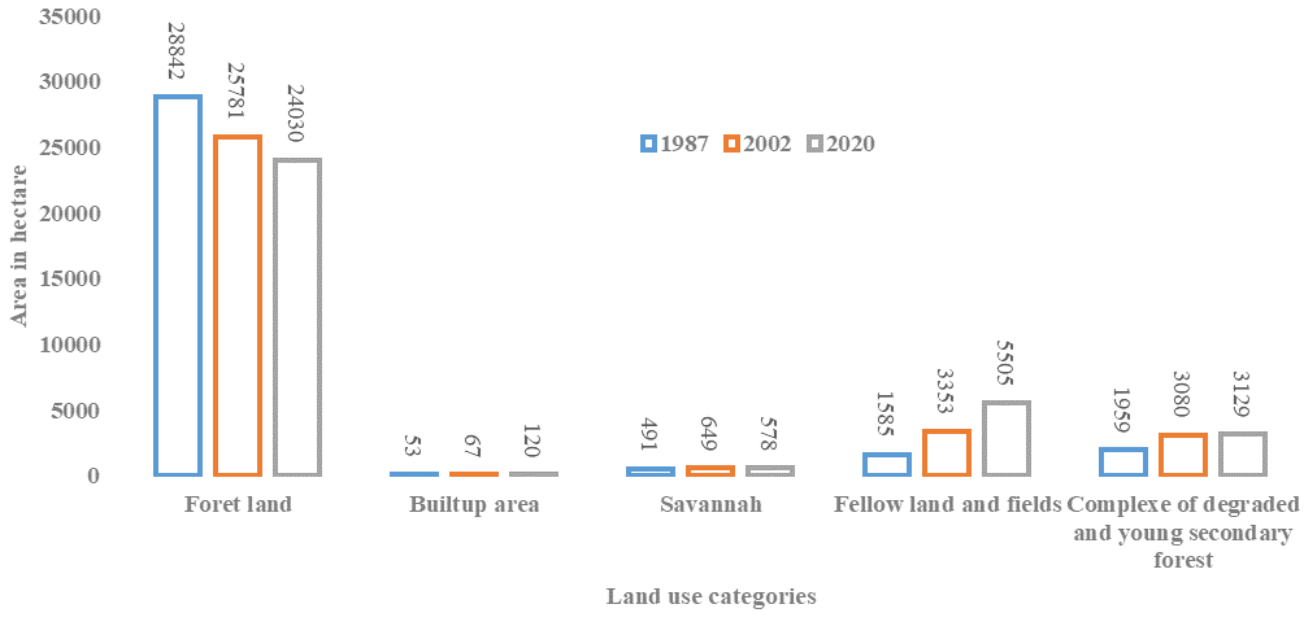

Figure 4. Land use/land cover statistics from 1987 to 2020

Table 4. Transition matrix (in \%) in the Luki's landscape

\begin{tabular}{|c|c|c|c|c|c|c|}
\hline & Land Use Class & Forest land & $\begin{array}{l}\text { Complex of degraded } \\
\text { and young } \\
\text { Secondary forest } \\
\end{array}$ & Savannah & $\begin{array}{c}\text { Fallow } \\
\text { Land }\end{array}$ & $\begin{array}{c}\text { Built-up } \\
\text { Area }\end{array}$ \\
\hline \multirow{5}{*}{$\begin{array}{c}1987 \text { to } \\
2020\end{array}$} & Forest land & 82.12 & 4.06 & 0.48 & 13.26 & 0.08 \\
\hline & $\begin{array}{l}\text { Complex of } \\
\text { degraded and } \\
\text { young Secondary } \\
\text { forest }\end{array}$ & 0.005 & 90.88 & 0.799 & 7.865 & 0.45 \\
\hline & Savannah & 0.000 & 7.9824 & 83.449 & 1.556 & 7.012 \\
\hline & Fallow land & 0.267 & 7.46 & 0.346 & 91.418 & 0.510 \\
\hline & Built-up area & 0.0000 & 2.555 & 9.000 & 0.852 & 87.5639 \\
\hline
\end{tabular}

The transition matrix (Table 5) offers the full pattern of change for all land use/land cover categories in the Luki Biosphere Reserve. From 1987 to 2020, the forest land lost the greatest amount of area. Also, the biggest forest land area was transformed into fallow land and fields, followed by the complex of degraded and young secondary forest, savannah, and built-up area. 
Table 5. Land use/land cover statistics (in hectare) from 1987 to 2020 in the Luki's landscape

\begin{tabular}{c|c|c|c}
\hline Land Use Class & $\mathbf{1 9 8 7}$ & $\mathbf{2 0 0 2}$ & $\mathbf{2 0 2 0}$ \\
\hline Forest land & 30818.71 & 28876.17 & 26812.69 \\
Non-forest & 2128.59 & 4071.12 & 6132.72 \\
\hline
\end{tabular}

In fact, due to the expansion of human activities, particularly agriculture, more than $13.26 \%$ of forest land was transformed into fallow land and fields. Further, the fallow land and field class has been identified as the class that gained the biggest area, principally transformed from forest land, the complex of degraded and young secondary forest (7.8\%), savannah (1.5\%), and built-up area (0.8\%). Nevertheless, the absence of human activities in the fallow land (4\%) converted from forest land, has led to the natural evolution of this class to young secondary forest. Moreover, the overexploitation of forest land areas $(0.48 \%)$ over a long period has been resulted in their transformation into savannah class.

However, after grouping land use classes in two groups for the purpose of implementing the logistic regression model, it has revealed a decrease in forest land while the non-forest land increased from 1987 to 2020, as shown in Table 5 and Figure 5.

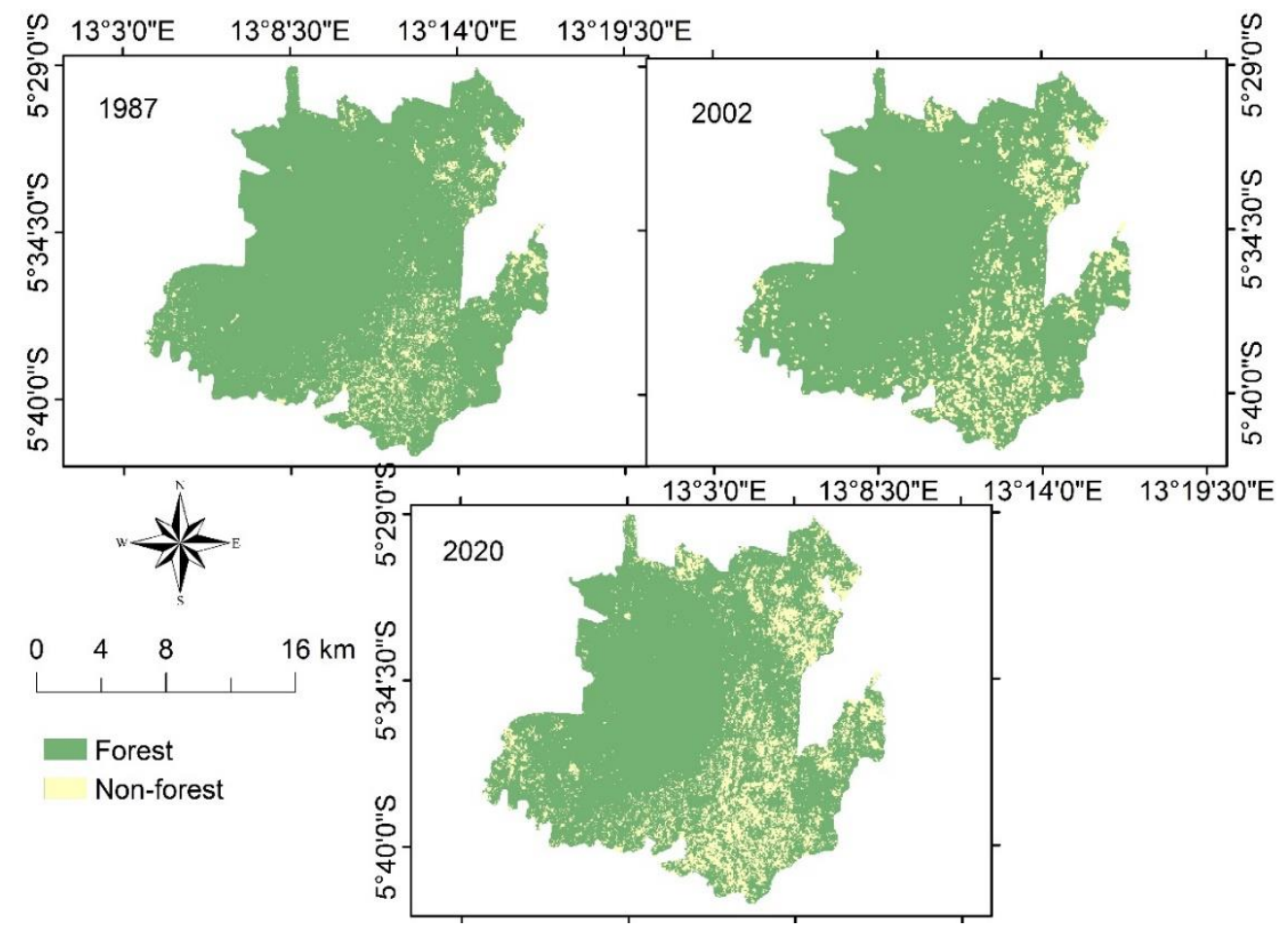

Figure 5. Land use/land cover change

\section{Multicollinearity and correlation analyses between the drivers for different LULC conversions}

In this study, the Pearson method was used to examine the correlation between different drivers selected to perform the logistic regression. As shown in Figure 6, all the explanatory variables were weakly correlated, and none of them had correlation values greater than 0.5. All the drivers were positively correlated to other variables except for 
the population density that was negatively correlated. A strong correlation between elevation and slope was observed, although it did not reach the value of 0.5 for both periods under study (1987-2002 and 2002-2020). The variance inflation factor (VIF) was used to test the multicollinearity of independent variables. Meanwhile, different authors have demonstrated that, variables with VIF values greater than 10 are not suitable for modelling analysis (Field, 2013). In this study, the VIF values for all independent variables ranged from 1.054 to 1.097 (Table 6). These values were acceptable, thus, all drivers were included in the model. Finally, the tolerance value that expresses the percentage of variation related to the variable was found to be greater than 0.8 for all the independent variables, suggesting that multicollinearity was not a limitation when computing the variable coefficients using the logistic regression model.
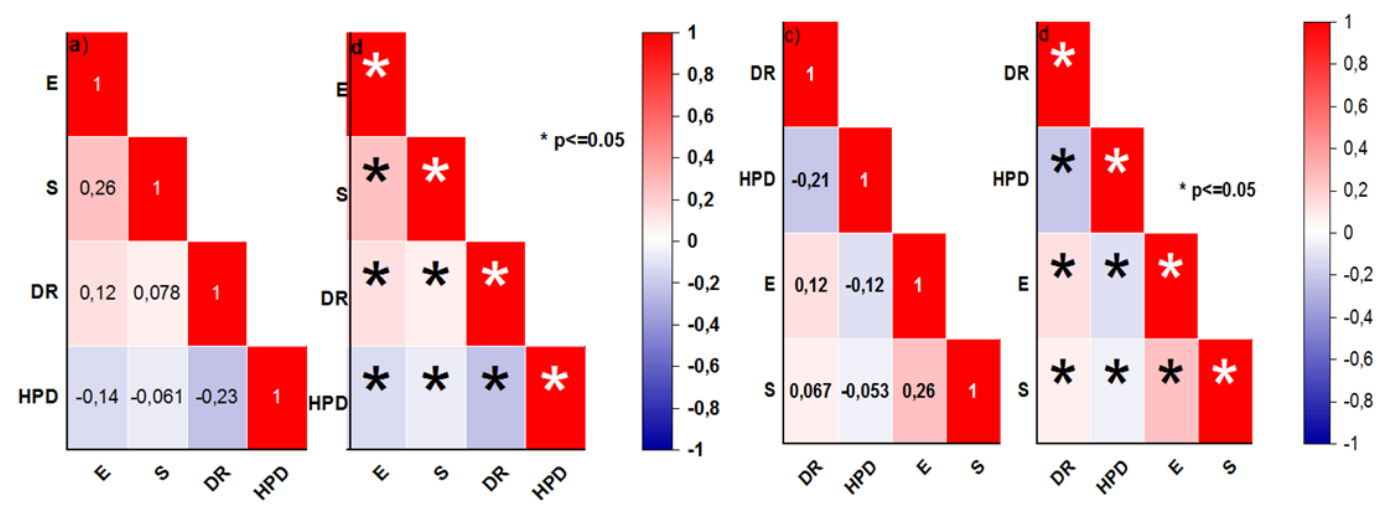

Figure 6. Correlation analysis of drivers for; a) 1987-2002 b) significance level c) 2002-2020 d) significance level. (E: elevation, S: slope, DR: distanceto roads, HPD: human population density)

Table 6. Multicollinearity analysis of drivers for different LULC conversions

\begin{tabular}{c|c|c|c}
\hline LULC conversions & Variables & Tolerance & VIF \\
\hline \multirow{2}{*}{ Forest lands to others } & Elevation & 0.912 & 1.097 \\
& Slope & 0.931 & 1.074 \\
\multirow{2}{*}{$1987-2002$} & Distance to roads & 0.939 & 1.065 \\
& Population density & 0.936 & 1.063 \\
\hline \multirow{2}{*}{ Forest lands to others } & Elevation & 0.917 & 1.091 \\
& Slope & 0.933 & 1.072 \\
$2002-2020$ & Distance to roads & 0.946 & 1.057 \\
& Population density & 0.949 & 1.054 \\
\hline
\end{tabular}

\section{Modelling LULC change based logistic regression}

Odds ratios (ORs) were used to measure the effects of spatial drivers of deforestation in the Luki Reserve as illustrated in Table 7. During the period under study, major changes have been observed in forest land, leading to the decrease of forest land area. Thus, the effects of underlying variables that had driven the observed changes were thoroughly analysed. These variables include distance from roads, slope, and elevation and population density. Based on the obtained results, it was evident that all the explanatory 
variables had significantly impacted the forest change during the period under study, with p-value being less than 0.05 . The proximity to roads significantly increased the conversion probability of forest land to other land use types by 2.569 and 2.768 (p-value < 0.05), respectively from 1987-2002 and 2002-2020. In addition, an increase in population density significantly increased the conversion probability of forest lands to other land use types by 2.191 and 2.357 (p-value<0.05), respectively from 1987-2002 and 2002-2020. It is worth noting that these two independent variables (proximity to roads and population density) were found to be the most important drivers that strongly affected the process of deforestation in the Luki biosphere reserve during the period under study.

Table 7. Drivers affecting the conversion of LULC categories in the Luki biosphere reserve

\begin{tabular}{c|c|c|c}
\hline LULC conversion & Independent variables & Odd ratio & p-value \\
\hline \multirow{2}{*}{ Forest lands to others } & Distance to roads & $2.569^{*}$ & $<0.05$ \\
& Elevation & $1.120^{*}$ & $<0.05$ \\
\multirow{2}{*}{$1987-2002$} & Slope & $0.976^{*}$ & $<0.05$ \\
& Population density & $2.191^{*}$ & $<0.05$ \\
\hline \multirow{2}{*}{ Forest lands to others } & Distance to roads & $2.768^{*}$ & $<0.05$ \\
& Elevation & $1.235^{*}$ & $<0.05$ \\
$2002-2020$ & Slope & $0.998^{*}$ & $<0.05$ \\
& Population density & $2.357^{*}$ & $<0.05$ \\
\hline
\end{tabular}

The selected drivers were found to affect forest conversion process in the Luki Biosphere Reserve between 1987 and 2020. Areas closer to roads experienced significant change, especially the conversion from primary forest to fallow land and fields. Similarly, the closer the area to highly populated areas, the higher the conversion probability from forest land to other land use categories. These two drivers (proximity to roads and areas with high population density) were the most significant contributors of forest conversion in the Luki biosphere reserve. Meanwhile, slope and elevation also significantly impacted the conversion of forest land to other land use types, but when compared to proximity to roads and population density, their effects were moderate. Areas with low slope were expected to experience a high probability of conversion, compared to areas with high slope.

\section{Discussion}

The present research examined the spatial drivers of deforestation in the Luki Biosphere Reserve during the last three decades (1987-2020). Remote sensing data and modeling techniques were used to perform land use/land cover change and examine the pattern of spatial drivers (distance to roads, population density, elevation and slope) affecting this change.

From our analysis, major landscape changes were found to have occurred during the study period, leading to forest loss and the expansion of agricultural land and built-up area, as reported by other studies done in other regions (Lambin et al., 2001; Bamba, 2010; Mpoyi et al., 2013; Ciza et al., 2015; Ngabinzeke et al., 2016; Kyale et al., 2019; Opelele et al., 2020). Numerous spatial variables have been known to play a significant role in driving the land use/land cover changes (Ouedraogo et al., 2010). 
However, in the Luki Biosphere Reserve, the observed changes have been significantly induced by spatial drivers such as population density, distance to roads, as well as elevation and slope. Of these, population density and proximity to roads were the most significant spatial drivers of deforestation in the Luki Biosphere Reserve; and their relative importance did not change according to the two periods chosen for the present study. Furthermore, the proximity to roads and high population led to massive conversion of forest land to other land use/land cover types. This conversion increased with high population density and proximity to roads, then with elevation and slope. Our findings are consistent with previous reports (van Gils and Loza, 2006; Mhawish and Saba, 2008; Siles, 2009; Buckley, 2010; Kyale et al., 2019) which demonstrated the impact of population density and road network in the land use/land cover change process. These drivers increase the susceptibility of forest lands to conversion into other land use types due to the dependency of local community on forest resources, and promotion of intense trade of forest products. According to Mhawish and Saba (2016) and Verburg and Overmars (2009), the population density is one of the main drivers of land use/land cover change that can influence change from local to large scale. Also, among five explanatory variables (distance from roads and settlements, topography, land tenure, and soil texture), Loza (2004) has revealed a high significant relationship between distance from roads and forest conversion. In fact, the population growth and economic development of surrounding cities of the Luki forest led to the increase of land and natural resource demands, thus acting as significant drivers of deforestation and forest degradation. Meanwhile, agriculture is the main source of livelihoods for the local communities. As such, crop fields have been established in areas closer to roads and human settlements. This has increased the impact of these two drivers on land use conversion.

With respect to slope and elevation, major conversion types were found to mostly occur in flatter zones in our study area. These findings were consistent with reports from previous studies (Mertens and Lambin, 1997; Qasim et al., 2013). These studies showed that low elevation is more associated to agriculture and agglomeration expansion due to the high accessibility, while steeper areas are suitable for forest lands (Mertens and Lambin, 1997; Qasim et al., 2013). The present study revealed the significant role of accessibility variables on forest change, compared to topographical variables. Our results corroborate with previous studies in other regions (Linkie et al., 2004; Mas et al., 2004; Lesschen et al., 2005).

The area under curve, as presented in Figure 7, was estimated at $76.5 \%$ and $81.9 \%$ for the period 1987-2002 and 2002-2020, respectively. This provides $76.5 \%$ and $81.9 \%$ of accuracy of our prediction results. Loza (2004) and Siles (2009), in their studies on examining the effects of spatial drivers on forest conversion, have estimated the area under curve at $71.50 \%$ and $87 \%$, respectively.

The approach of the logistic regression applied in the present research has been found to be most suitable technique to examine spatial dimension of the spatial drivers of deforestation, approving its potential in the field of regression analysis for binary dependent variables (Huang et al., 2009). Therefore, it is essential to properly analyze landscape changes and the factors that induce them in order to predict their future evolutions and subsequently support the decision-making processes from a perspective of multiple scenarios. The present study considered only four variables in the model since data for other variables such as temperature, soil type and precipitation were not available for this research. Thus, it would be important for future studies to include other variables in the model to further improve its precision. 
However, Huang et al. (2009) pointed out that in a model of land use change, the use of a limited number of variables is very useful to providing a better understanding of land use/land cover change involving complex processes, as revealed in this study. Finally, with spatial resolution as low as $30 \mathrm{~m}$, the use of Landsat images in this study may have had an impact on the pattern of change observed in the Luki landscape. Images of low spatial resolution often induce mixed pixel problems when used in the classification of heterogeneous vegetation. Thus, the use of high spatial resolution can solve the problem of mixed pixels, as we used Landsat images that had coarse resolution.
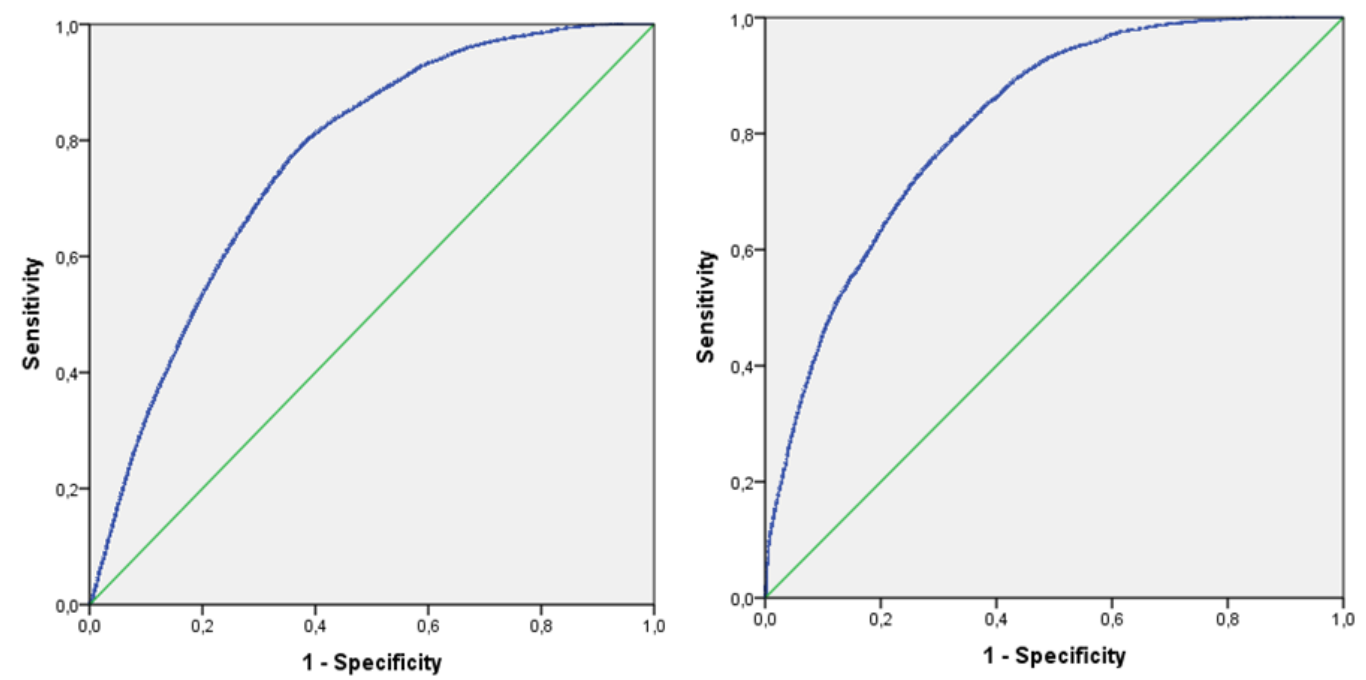

Figure 7. Validation of the logistic regression model prediction (AUC/ROC). A) 1987-2002, and b) 2002-2020

\section{Conclusions}

The present study revealed an enormous decrease in area of forest land in the Luki Biosphere Reserve during the studied period (1987-2020). A number of human pressures such as agriculture, illegal logging, village expansion has mainly caused forest losses in the study area. It has been found that these changes have been significantly associated with factors such as distance from roads, population density, slope, and elevation. However, it was noted that population density and distance from roads were the most important spatial drivers of deforestation in the region. Indeed, areas closer to roads and highly populated villages are expected to experience the higher probability of forest conversion. The logistic regression model has been found to be an efficient tool to model spatial drivers associated with deforestation and facilitated in examining their relative importance on the deforestation process. The present study provides reliable information that managers, policy-makers and local authorities should include in their decision making processes for the purpose of environmental monitoring and planning, prediction analysis and impact assessment at local level. However, considering the limitation of data related to intensification of farming, future studies should incorporate this variable when establishing the model. Household surveys could also be conducted to provide socioeconomic data related to household forest dependence for developing decision models for sustainable land management. 
Funding. This study was supported by The Fundamental Research Funds for the Central Universities (2572019CP12).

\section{REFERENCES}

[1] Adhikari, A., Hansen, A. J. (2018): Land use change and habitat fragmentation of wildland ecosystems of the North Central United States. - Landscape and Urban Planning 177: 196216. https://doi.org/10.1016/j.landurbplan.2018.04.014.

[2] Al Kafy, A., Abdullah-Al, F., Al Rakib, A., Abdullah Al, R., Shaleha, K. A., Zullyadini, A. R., Dewan, A. J., Gangaraju, S., Opelele, O. M., Abhishek, B. (2021): The operational role of remote sensing in assessing and predicting land use/land cover and seasonal land surface temperature using machine learning algorithms in Rajshahi, Bangladesh. - Applied Geomatics 13: 793-816.

[3] Angoboy, I. B., Beeckman, H., Ouédraogo, D. Y., Bourland, N., De Mil, T., Van Den Bulcke, J., Van Acker, J., Couralet, C., Ewango, C., Hubau, W., Toirambe, B., Doucet, J. L., Fayolle, A. (2019): Une forte saisonnalité du climat et de la phénologie reproductive dans la forêt du Mayombe: l'apport des données historiques de la Réserve de Luki en République démocratique du Congo. - Bois et Forêts des Tropiques 341: 39-53. https://doi.org/10.19182/ bft2019.341.a31753.

[4] Arekhi, S. (2011): Modeling spatial pattern of deforestation using GIS and logistic regression: a case study of northern Ilam forests, Ilam province, Iran. - Afr. J. Biotechnol. 10(72): 16236-16249.

[5] Bamba, I. (2010): Anthropisation et dynamique spatio-temporelle de paysages forestiers en République démocratique du Congo. - Available online at: https://www.congoforum.be/Upldocs/Forets\%20These_finale_IBAMBA.pdf (accessed on 7 May 2021).

[6] Buckley, A. (2010): ESRI ArcGIS Blog. - Understanding curvature rasters.

[7] Buya, S., Tongkumchum, P., Owusu, B. E. (2020): Modelling of land-use change in Thailand using binary logistic regression and multinomial logistic regression. - Arabian Journal of Geosciences 13(12). https://doi.org/10.1007/s12517-020-05451-2.

[8] Ciza, S. K., Mikwa, J. F., Malekezi, A. C., Gond, V., Bosela, F. B. (2015): Identification des moteurs de déforestation dans la région d'Isangi, République démocratique du Congo. - Bois Forets des Tropiques 324: 29-38. https://doi.org/10.19182/bft2015.324.a31264.

[9] Congalton, R. G., Mead, R. A. (1983): A quantitative method to test for consistency and correctness in photo-interpretation. - Photogrammetric Engineering and Remote Sensing 49(1): 69-74.

[10] Diuk-Wasser, M. A., Vanacker, M. C., Fernandez, M. P. (2021): Impact of Land Use Changes and Habitat Fragmentation on the Eco-epidemiology of Tick-Borne Diseases. Journal of Medical Entomology 58(4): 1546-1564. https://doi.org/10.1093/jme/tjaa209.

[11] Doumenge, C. (1990): La Conservation des Écosystèmes Forestiers du Zaïre. - UICN: Gland, Switzerland, 242p.

[12] Field, A. (2013): Discovering statistics using IBM SPSS statistics. Statistics (58). - SAGE Publications Ltd.

[13] Foley, J. A., DeFries, R., Asner, G. P., Barford, C., Bonan, G., Carpenter, S. R., Chapin, S., Coe, M. T., Daily, G. C., Gibbs, H. K., Helkowski, J. H., Holloway, T., Howard, E. A., Kucharik, C. J., Monfreda, C., Patz, J. A., Prentice, I. C., Ramankutty, N., Snyder, P. K. (2005): Global consequences of land use. - Science 309: 570-574.

[14] Gata, D. (1997): Etudes des Impacts Humains, Estimation De Degré de Péril de la Biodiversité et Principes Directeurs pour une Gestion Durable des Ressources Disponibles. - MAB: Kinshasa, Democratic Republic of Congo, 37p. 
[15] Geist, H. J., Lambin, E. F. (2001): What Drives Tropical Deforestation? A meta-analysis of proximate and underlying causes of deforestation based on subnational case study evidence. - LUCC International Project Office 5: 207-210.

[16] González, M. G., Martínez, M., Lithgow, D., Pérez-Maqueo, O., Simonin, P. (2012): Land use change and its effects on the value of ecosystem services along the coast of the Gulf of Mexico. - Ecol. Econ 82: 23-32. https://doi.org/10.1016/j.ecolecon.2012.07.018.

[17] Hanley, J. A., McNeil, B. J. (1983): A method of comparing the areas under receiver operating characteristic curves derived from the same cases. - Radiology 148: 839-843.

[18] Harris, I., Osborn, T. J., Jones, P., Lister, D. H. (2020): Version 4 of the CRU TS monthly high-resolution gridded multivariate climate dataset. - Sci. Data 7: 109.

[19] Henders, S., Persson, U. M., Kastner, T. (2015): Trading forests: Land-use change and carbon emissions embodied in production and exports of forest-risk commodities. Environmental Research Letters 10: 12. https://doi.org/10.1088/1748-9326/10/12/125012.

[20] Huang, B., Zhang, L., Wu, B. (2009): Spatiotemporal analysis of rural-urban land conversion. - Int. J. Geogr. Inf. Sci. 23(3): 379-398. https://doi.org/10.1080/13658810802119685.

[21] Kamwi, J. M., Chirwa, P. W. C., Manda, S. O. M., Graz, F. P., Kätsch, C. (2015): Livelihoods, land use and land cover change in the Zambezi Region, Namibia. - Popul. Environ. 37(2): 207-230. https://doi.org/10.1007/s11111-015-0239-2.

[22] Keshtkar, H., Voigt, W., Alizadeh, E. (2017): Land-cover classification and analysis of change using machine learning classifiers and multi-temporal remote sensing imagery. Arabian Journal of Geosciences 10: 6. https://doi.org/10.1007/s12517-017-2899-y.

[23] Kyale, K. J., Wardell, D. A., Mikwa, J. F., Kabuanga, J. M., Monga Ngonga, A. M., Oszwald, J., Doumenge, C. (2019): Dynamique de la déforestation dans la Réserve de biosphère de Yangambi (République démocratique du Congo): variabilité spatiale et temporelle au cours des 30 dernières années. - Bois et Forêts des Tropiques 341: 15. https://doi.org/10.19182/bft2019.341.a31752.

[24] Lambin, E. F., Turner, B. L., Geist, H. J., Agbola, S. B., Angelsen, A., Bruce, J. W., Coomes, O. T., Dirzgo, R., Fischer, G., Folke, C., George, P. S., Homewood, K., Imbernon, J., Leemans, R., Li, X., Moran, E. F., Mortimore, M., Ramakrishnan, P. S., Xu, J. (2001): The Causes of Land-Use and Land-Cover Change: Moving Beyond the Myths. - Glob. Environ. Change 11(4): 261-269. https://doi.org/10.1016/S0959-3780(01)00007-3.

[25] Lambin, E. (2006): Land Cover Assessment and Monitoring. Encyclopedia of Analytical Chemistry. - John Wiley \& Sons, Ltd. https://doi.org/10.1002/9780470027318.a2311.

[26] Lesschen, J. P., Verburg, P. H., Staal, S. J. (2005): Statistical Methods for Analysing the Spatial Dimension of Changes in Land Use and Farming Systems. - LUCC Focus 3 Office and ILRI.

[27] Li, W., Ciais, P., Peng, S., Yue, C., Wang, Y., Thurner, M., Saatchi, S., Arneth, A., Avitabile, V., Carvalhais, N., Harper, A., Kato, E., Koven, C., Liu, Y., Nabel, J., Pan, Y., Pongratz, J., Poulter, B., Pugh, T., Santoro, M., Sitch, S., Stocker, B., Viovy, N., Wiltshire, A., Yousefpour, R., Zaehle, S. (2017): Land-use and land-cover change carbon emissions between 1901 and 2012 constrained by biomass observations. - Biogeosciences 14(22): 5053-5067. https://doi.org/10.5194/bg-14-5053-2017.

[28] Linkie, M., Smith, R. J., Leader-Williams, N. (2004): Mapping and predicting deforestation patterns in the lowlands of Sumatra. - Biodivers. Conserv. 13: 1809-1818.

[29] Loza, A. V. (2004): Spatial logistic model for tropical forest conversion : a case study of Carrasco province (1986-2002), Bolivia. - International Institute for Geoinformation Science and Earth Observation, Enschede, The Netherlands.

[30] Lubalega, T. K., Mananga, P. M. (2018): Évaluation de la biodiversité spécifique ligneuse des cultures agricoles sous couvert arboré à Patu, dans le Mayombe, en République Démocratique du Congo (RDC). - CongoSciences 6: 2.

[31] Lubini, A. (1997): La végétation de la Réserve de Biosphère de Luki au Mayombe (RD Congo). - Opera Botanica Belgica 10: 155. 
[32] Maitima, J. M., Olson, J. M., Mugatha, S. M., Mugisha, S., Mutie, T. (2010): Land use changes, impacts and options for sustaining productivity and livelihoods in the basin of Lake Victoria. - J. Sustain. Dev. Afr. 12(3): 1520-5509.

[33] Mas, J. F., Puig, H., Palacio, J. L., Sosa-López, A. (2004): Modelling deforestation using GIS and artificial neural networks. - Environ. Model. Softw. 19: 461-471.

[34] McConnell, W. J. (2015): Land Change: The Merger of Land Cover and Land use Dynamics. - International Encyclopedia of the Social \& Behavioral Sciences (Second Edition). Oxford: Elsevier, 220-3.

[35] Mertens, B., Lambin, E. F. (1997): Spatial modeling of tropical deforestation in southern Cameroon: spatial disaggregation of diverse deforestation processes. - Appl. Geogr. 17: 143-162.

[36] Metz, C. E. (1978): Basic principles of ROC analysis. - Seminars in Nuclear Medicine 8: 283-298.

[37] Mhawish, Y. M., Saba, M. (2016): Impact of Population Growth on Land Use Changes in Wadi Ziqlab of Jordan between 1952 and 2008. - International Journal of Applied Sociology 6(1): 7-14. Retrieved from http://journal.sapub.org/ijas.

[38] Moghadasi, N., Karimirad, I., Sheikh, V. (2017): Assessing the impact of land use changes and rangeland and forest degradation on flooding using watershed modeling system. Journal of Rangeland Science 7(2): 93-106. https://doi.org/10.5772/intechopen.77041.

[39] Mpoyi, A. M., Nyamwoga, F. B., Kabamba, F. M., Assembemvondo, S. (2013): Le contexte de la REDD+ en République Démocra-tique du Congo Causes, agents et institutions. - CIFOR, Bogor. https://doi.org/10.17528/cifor/004094.

[40] Mustafa, A., Rienow, A., Saadi, I., Cools, M., Teller, J. (2018): Comparing support vector machines with logistic regression for calibrating cellular automata land use change models. - European Journal of Remote Sensing 51(1): 391-401. https://doi.org/10.1080/22797254.2018.1442179.

[41] Nandy, S., Kushwaha, S. P. S., Mukhopadhyay, S. (2007): Monitoring Chilla-Motichur corridor using geospatial tools. - J. Nat. Conserv. 15(4): 237-244.

[42] Ngabinzeke, J. S., Linchant, J., Quevauvillers, S., Muhongya, J. M. K., Lejeune, P., Vermeulen, C. (2016): Cartographie de la dynamique de terroirs villageois à l'aide d'un drone dans les aires protégées de la République démocratique du Congo. - Bois Forets des Tropiques 315: 21-28. https://doi.org/10.19182/bft2016.330.a31320.

[43] Nyange, N. M. (2014): Participation des communautés locales et gestion durable des forêts: Cas de la réserve de la biosphère de Luki en République Démocratique du Congo. - Ph.D. Thesis, Université Laval Québec, Québec, QC, Canada, 227p. Available online: https://corpus.ulaval.ca/jspui/bitstream/20.500.11794/25349/1/30892.pdf (accessed on 2 May 2021).

[44] Olaya, V. (2009): Basic land-surface parameters. - Developments in Soil Science 33: 141169. https://doi.org/10.1016/S0166-2481(08)00006-8.

[45] Opelele, O. M., Fan, Y., Yu, Y., Kachaka, S. K. (2020): Analysis of land use/land cover change and its prediction in the Mambasa sector, Democratic Republic of Congo. - Applied Ecology and Environmental Research 18(4): 5627-5644. https://doi.org/10.15666/aeer/1804_56275644.

[46] Opelele, O. M., Ying, Y., Fan, W., Chen, C., Kachaka, S. K. (2021): Examining Land Use/Land Cover Change and Its Prediction Based on a Multilayer Perceptron Markov Approach in the Luki Biosphere Reserve, Democratic Republic of Congo. - Sustainability 13: 6898.

[47] Opelele, O. M., Yu, Y., Fan, W., Lubalega, T., Chen, C., Kachaka, S. K. (2021): Analysis of the Impact of Land-Use/Land-Cover Change on Land-Surface Temperature in the Villages within the Luki Biosphere Reserve. - Sustainability 13(20): 11242. https://doi.org/10.3390/su132011242. 
[48] Ouedraogo, I., Tigabul, M., Savadogo, P., Compaore, H., Odén, P. C., Ouadba, J. M. (2010): Land cover change and its relation with population dynamics in Burkina Faso,West Africa. - Land Degrad. Dev. 21(5): 453-462. https://doi.org/10.1002/ldr.981.

[49] Overmars, K. P., Verburg, P. H. (2005): Analysis of land use drivers at the watershed and household level: Linking two paradigms at the Phillipine forest fringe. - Int. J. Geogr. Inf. Sci. 19: 125-152. https://doi.org/10.1080/13658810410001713380.

[50] Peel, M. C., Finlayson, B. L., Mcmahon, T. A. (2007): Updated world map of the KöppenGeiger climate classification. - Hydrology and Earth System Sciences 11: 1633-1644. https://doi.org/10.5194/hess-11-1633-2007.

[51] Pendje, G., Mbaya, M. (1992): La réserve de Biosphère de Luki, Patrimoine Floristique et Faunique en Péril. - UNESCO: Paris, France, 62p.

[52] Pijanowski, B. C., Pithadia, S., Shellito, B. A. (2005): Calibrating a neural network-based urban change model for two metropolitan areas of the Upper Midwest of the United States. - International Journal of Geographical Information Science 19(2): 197-215. https://doi.org/10.1080/13658810410001713416.

[53] Pontius Jr., R. G., Schneider, L. C. (2001): Land-cover change model validation by an ROC method for the Ipswich watershed, Massachusetts, USA. - Agric. Ecosyst. Environ. 85(13): 239-248.

[54] Pontius Jr., R. G., Malanson, J. (2005): Comparison of the structure and accuracy of two land change models. - Int. J. Geogr. Inf. Sci. 19(2): 243-265.

[55] Powers, R. P., Jetz, W. (2019): Global habitat loss and extinction risk of terrestrial vertebrates under future land-use-change scenarios. Nature Climate Change. - Nature Publishing Group. https://doi.org/10.1038/s41558-019-0406-z.

[56] Qasim, H., Klaus, H., Termansen, M., Fleskens, L. (2013): Modelling Land Use Change across Elevation Gradients in District Swat, Pakistan. - Regional Environmental Change 13(3): 567-581. https://doi.org/10.1007/s10113-012-0395-1.

[57] Rawat, J. S., Kumar, M. (2015): Monitoring land use/cover change using remote sensing and GIS techniques: A case study of Hawalbagh block, district Almora, Uttarakhand, India. - The Egyptian Journal of Remote Sensing and Space Science 18: 77-84. https://doi.org/10.1016/j.ejrs.2015.02.002.

[58] Sénéchal, J., Kabala, M., Fournier, F. (1989): Revue des connaissances sur le Mayombe. Paris, France, Unesco, 343p.

[59] Sharma, R., Nehren, U., Rahman, S. A., Meyer, M., Rimal, B., Seta, G. A., Baral, H. (2018): Modeling land use and land cover changes and their effects on biodiversity in Central Kalimantan, Indonesia. - Land 7(2). https://doi.org/10.3390/land7020057.

[60] Sharma, R., Rimal, B., Baral, H., Nehren, U., Paudyal, K., Sharma, S., Rijal, S., Ranpal, S., Alenazy, A., Kandel, P. (2019): Impact of land cover change on ecosystem services in a tropical forested landscape. - Resources 8(1). https://doi.org/10.3390/resources8010018.

[61] Siles, N. J. S. (2009): Spatial Modelling and prediction of tropical for-est conversion in the Isiboro Secure National Park and Indigenous Territory(TIPNIS), Bolivia. - International Institute for Geoinformation Science and Earth Observation, Enschede, The Netherlands.

[62] Sperandei, S. (2014): Understanding logistic regression analysis. - Biochemia Medica 24(1): 12-18. https://doi.org/10.11613/BM.2014.003.

[63] Sulieman, H. M. (2018): Exploring divers of forest degradation and fragmentation in Sudan: The case of Erawashda Forest and its surrounding community. - Science of the Total Environment 621: 895-904. https://doi.org/10.1016/j.scitotenv.2017.11.210.

[64] Sun, J., Southworth, J. (2013): Remote sensing-based fractal analysis and scale dependence associated with forest fragmentation in an Amazon tri-national frontier. - Remote Sens. 5: 454-472.

[65] Vadrevu, K. P. (2013): Introduction to Remote Sensing. Fifth Ed. - In: Campbell, J. B., Wynne, R. H. (eds.) The Photogrammetric Record. Guilford Press New York.

[66] van Gils, H. A. M. J., Loza Armand Ugon, A. V. (2006): What drives conversion of tropical forest in Carrasco province, Bolivia? - Ambio 35(2): 81-85. 
[67] Verburg, P. H., Overmars, K. P. (2009): Combining top-down and bottom-up dynamics in land use modeling: Exploring the future of abandoned farmlands in Europe with the DynaCLUE model. - Landscape Ecology 24(9): 1167-1181. https://doi.org/10.1007/s10980009-9355-7.

[68] Wang, M., Cai, L., Xu, H., Zhao, S. (2019): Predicting land use changes in northern China using logistic regression, cellular automata, and a Markov model. - Arabian Journal of Geosciences 12(24). https://doi.org/10.1007/s12517-019-4985-9.

[69] Zhou, Y., Chen, M., Tang, Z., Mei, Z. (2021): Urbanization, land use change, and carbon emissions: Quantitative assessments for city-level carbon emissions in Beijing-TianjinHebei region. - Sustainable Cities and Society 66.

https://doi.org/10.1016/j.scs.2020.102701. 